\title{
Transplantation of Human Neuroblastoma Cells, Catecholaminergic and Non-Catecholaminergic: Effects on Rotational Behavior in Parkinson's Rat Model
}

\author{
Jacob S. Manaster ${ }^{1,3}$, Tony Feuerman ${ }^{2}$, C. Patrick Reynolds ${ }^{4}$ and Charles H. Markham ${ }^{1}$ \\ ${ }^{1}$ Department of Neurology, University of California at Los Angeles School of Medicine \\ Los Angeles, California 90024-1769 \\ ${ }^{2}$ Department of Surgery, Division of Neurosurgery \\ University of California School of Medicine \\ Los Angeles, CA 90024 \\ ${ }^{3}$ Department of Surgery, Cedars Sinai Medical Center \\ Los Angeles, CA 90048-1869 \\ ${ }^{4}$ Department of Hematology/Oncology \\ USC-Children's Hospital of Los Angeles \\ Los Angeles, CA 90054-0700 \\ USA
}

SUMMARY

Cultured human catecholaminergic and noncatecholaminergic donor cells were used in neural transplantation experiments in a rat model of Parkinson's disease. Using two different human catecholaminergic neuroblastoma cell lines, one control non-catecholaminergic neuroblastoma cell line, and one sham control (tissue culture medium), transplants were made into the striatum using a modified Ungerstedt hemiparkinsonian rat model. Significant decreases in apomorphine-induced rotational behavior were produced by two of three catecholaminergic cell lines. Grafted cells staining positively for tyrosine hydroxylase (TH) and catecholamine fluorescence indicated viable catecholamine activity in the two cell lines which produced reductions in rotational behavior. Catecholamine fluorescence was not detected in either of the two controls. These data suggest a link between catecholamine secretion by transplanted cells and motor improvement using a rat rotational behavior model.

Reprint address:

J.S. Manaster

Department of Neurology

UCLA School of Medicine

Los Angeles, CA 90024-1769, USA

\section{KEY WORDS}

dopamine, neuroblastoma, neural transplantation, substantia nigra, Parkinson's disease

\section{INTRODUCTION}

Since 1985, when Backlund et al. $/ 3$ / presented the first clinical tests of transplants of dopaminergic tissue in two Parkinson's patients, Parkinson's disease has been the focus of many transplant attempts. Neural tissue transplants have been performed on rats $/ 5 /$, monkeys /15/, and humans $/ 23 /$. Recent transplants to the striatum that utilized autologous human adrenal medullary dopamine-producing tissue have yielded variable results $/ 2,18 /$. Human fetal tissue transplants may offer greater promise /11, 24, 26/ but the complex moral and ethical issues raised by this procedure makes its potential for widespread human application uncertain. Experimental neural transplants in animals that use adrenal medullary grafts and fetal dopaminergic grafts have proved promising, producing good results in both rodents and primates $/ 7,27,31$. Another source of neurotransmitter-producing tissues are cultured cells which are transplanted into neurotransmitter deficient areas of the host brain. However, cell grafts consisting of cultured cells 
have yielded poor long term results $/ 32 /$ due to technical difficulties, primarily the severe disruption of the cell processes caused by dissociating cells $/ 14 /$, and secondarily the proper maintenance of tissue culture $132 /$. We transplanted cultured cells which are abundant, provoke no ethical problems, and may be genetically engineered. Furthermore, the use of cultured cells prevents the introduction of unrecognized infections or degenerative diseases.

Transplants of cultured cells to remedy experimental parkinsonism have been investigated /16, 19\%. (It has been possible to maintain satisfactory primary cultures of fetal neurons for long periods of time $/ 24,31 /$.) Numerous studies on intracerebral transplantation of various immortal cell lines into the rat striatum have been published in recent years. These include combined grafts of C6 glioma cells with chromaffin cells $/ 4 /$, a wide employment of PC-12 cells /1, 13, 21/, B16/C3 melanoma cells $/ 12 /$, and neuroblastoma cells similar to those employed here $/ 22 /$.

The approach involves injection of cultured, immortal cells through a needle into specific sites in the brain. The advantages of this method are the following: In comparison to whole tissue transplants, injection of cells in suspension appears to allow a more uniform and wider anatomical distribution of the donor cells over the entire needle track. Grafts into multiple sites and multiple injections in the same needle track might help the graft become better integrated with the host brain $/ 14 /$, and decrease tissue damage sometimes associated with whole tissue transplants in rats $/ 25 /$. Having several graft sites might better target specific dopamine deficient tissues, and injection of cells along the entire needle track and not just the base of the track will better disperse the cells, allowing increased integration with the host. This becomes important when attempting to influence a large structure such as the striatum in higher order animals $/ 10 \%$. Furthermore, immortal cell lines can provide an unlimited supply of cells. And finally, cell cultures may be genetically modified, as are the genetically modified temperature sensi- tive dopaminergic cells reported by Bredesen $e t$ al. /6/ and Whittemore et al. /37/ which stop dividing and mature at body temperature.

This study focuses upon catecholaminergic cells derived from neuroblastoma, suitable for neural transplants in the short term, like that of Horellou et al. /20/, and suggests why they might provide insight into the best ways to remedy parkinsonian deficits. We also suggest why a neuroblastoma control cell line that is noncatecholaminergic is unable to diminish a parkinsonian deficit.

A rotational behavior model for the study of nigro-striatal function was described by Ungerstedt $/ 33,35,36 /$. In the present study dopamine-producing and non-dopamine producing cell lines which both stain positively for TH were stereotactically introduced into the striatum deficient in dopamine, and alterations in rotational behavior observed.

To our knowledge the direct comparison of closely related dopaminergic and nondopaminergic cell lines which both express TH has not been attempted. The purpose of this study was to examine the capability of a catecholaminergic line to remedy parkinsonian behavior in the model, as well as to investigate the possibility of a more direct link between dopamine production and this model's behavioral improvement.

\section{MATERIALS AND METHODS}

The experimental protocol consisted of the following steps spanning four months: Rats received SN lesions, were allowed to mature for 1 month, were tested for rotational behavior in the following month, and those showing a constant frequency of rotations during at least 10 consecutive sessions (30 days) were selected for study. All animals chosen for transplant to the striatum ipsilateral to the damaged substantia nigra displayed at least 4 full body turns/min over a 10 min interval after the apomorphine had taken effect. A total of 27 lesioned rats fulfilled this criterion. Animals

Abbreviations: ANOVA, analysis of variance; AP, anterior/posterior; D, depth; EDTA, ethylene-diamine tetra acetic acid; H\&E, hemotoxylin and eosin; HEPES, hydroxy ethyl piperazine ethane sulfonic acid; L, lateral; 6-OHDA, six-hydroxydopamine; SN, substantia nigra; SPG, sucrose-potassium phosphate-glyoxylic acid; TH, tyrosine hydroxylase; VTA, ventral tegmental area. 
were randomly assigned to groups such that 7 received injections of the dopaminergic cell line LA-N-6, 8 received dopaminergic SMS-LHN, 6 received non-dopaminergic cell line SMS-KCN, and 6 received SHAM, i.e. tissue culture medium alone (Pucks-EDTA; Gibco) Apomorphine-induced rotational tests again were performed up to 30 days post-transplant. Mean rotations per minute were calculated for each animal. The rats were sacrificed 30 days after striatal transplant, and histochemical staining and immunofluorescence workups were performed on brain sections.

\section{Lesioning procedure}

The rats were anesthetized intraperitoneally with $50 \mathrm{mg} / \mathrm{kg}$ of nembutal. The 6-hydroxydopamine (6-OHDA) solution was prepared at room temperature by dissolving $2.6 \mathrm{mg}$ salt to produce $3 \mathrm{mg} / \mathrm{ml}$ of active base of 6-OHDA $(2,4,5-$ trihydroxyphenylalanine- $\mathrm{HCl}$ ) in $0.15 \mathrm{M}$ saline solution, with $0.2 \mathrm{mg} / \mathrm{ml}$ anhydrous ascorbic acid as a vehicle. Using a modification of the Ungerstedt method /34/, two unilateral lesions were made on male 250 gram Sprague-Dawley rats, one in the substantia nigra (SN) and one in the ventral tegmental area (VTA).

From the bregma the modified Ungerstedt coordinates of the lesion were: for VTA, AP was -5.3 $\mathrm{mm}, \mathrm{L}-0.7 \mathrm{~mm}$, and D $-8.3 \mathrm{~mm}$ from bregma; for $\mathrm{SN}, \mathrm{AP}$ was $-5.3 \mathrm{~mm}, \mathrm{~L}-2.5 \mathrm{~mm}$, and D $-8.3 \mathrm{~mm}$. A slow, gradual $5 \mu \mathrm{l}$ injection of 6-OHDA solution at the coordinates was administered over a $5 \mathrm{~min}$ period at a rate of $1 \mu \mathrm{l}$ per minute using a 25 gauge $10 \mu \mathrm{l}$ micro syringe (Hamilton Co., Reno, Nevada) fixed to a micromanipulator. The syringe was withdrawn slowly $5 \mathrm{~min}$ after the last increment of injection, the incision sutured and the animal allowed to recover.

\section{Rotational behavior}

Three days after striatal transplants, apomorphine-induced rotational trials were started, and continued every 3 days for four weeks, for a total of 10 sessions. Animals were injected intraperitoneally with a $250 \mu \mathrm{g} / \mathrm{kg}$ solution of apomorphine in sterile water, then placed in a black topless plexiglass $24 \times 24 \times 24$ inch box. After waiting for 15 $\min$ for the apomorphine to take effect, we then observed rotational movement for $10 \mathrm{~min}$ and calculated number of complete rotations/min. The means of data from 2 animals which expired prior to completing the $\mathbf{3 0}$ days of post-transplant testing, one each from SMS-LHN and SHAM, were also calculated.

\section{Statistical methods}

We measured the number of rotations per minute every three days up to 30 days before transplant procedures and every three days up to 30 days after transplant. The value of each day for each animal was the number of rotations for the 10 minute measurement divided by 10 , resulting in a value in units of rotations per minute. We defined the Baseline value as the mean of the last five pre-transplant measurements. We defined the Post-transplant value as the mean of the ten post-transplant measurements. To establish group comparability we used a one-way analysis of variance (ANOVA) to test the null hypothesis that the four group baseline means were equal.

To investigate the effect of the transplant we derived for each rat two measures from the baseline and the post-transplant values. One measure was the Change (baseline minus post-transplant) in number of rotations per minute. The other measure was the Percent Improvement (100 times Change divided by the baseline value). For each group we used a t-test on each measure to test the null hypothesis of mean zero.

To compare the four groups on Change and Percent Improvement we used an ANOVA to test the null hypothesis of equal means. Pairwise comparisons were performed using the Bonferroni approach.

All tests were two-tailed. Significance was defined as a p-value less than 0.01 . Because of the small sample size and the exploratory nature of the study we also report $p$-values less than 0.10 .

\section{Donor cell lines}

Three neuroblastoma cell lines and one tissueculture substance were transplanted. SMS-LHN and LA-N-6 are examples of relatively slow-growing neuroblastoma while SMS-KCN grows faster. 
All cell cultures were established from surgically removed human primary abdominal tumors. Cells were maintained at $37^{\circ} \mathrm{C}$ in a humidified $5 \%$ $\mathrm{CO}_{2}$ atmosphere incubator in RPMI 1640 with $10 \%$ fetal bovine serum.

SMS-LHN cells did not show catecholamine fluorescence in vitro, but were TH positive in freshly stained tumor tissue and in vitro /28/. SMSLHN and LA-N-6 tumor tissue exhibited marked catecholamine fluorescence when excised $/ 34 /$. The control SMS-KCN cell line is similar in ultrastructure, neurite outgrowth, neuron-specific enolase, and neurotransmitter biosynthetic enzymes (choline acetyltransferase, tyrosine hydroxylase, aromatic L-amino acid decarboxylase, and dopamine beta-hydroxylase) to SMS-LHN and LA-N-6 cell lines $/ 10,29 \%$. However, the SMS-KCN line was derived from a tumor that showed no evidence of catecholamine production by glyoxylic acid catecholamine fluorescence and immunohistochemistry at the time of excision, and also showed no fluorescence in vitro /28/. The SMS-KCN line served as an important control because of its overall similarities to the other lines with the exception of its lack of catecholamine production both in the donor patient and in cell culture. The other control consisted of injecting tissue culture medium (Pucks-EDTA) only.

Cells were harvested from tissue culture flasks non-enzymatically with Pucks saline A using 10 mM HEPES and $1 \mathrm{mM}$ EDTA (Pucks-EDTA) /28/, and triturated into a single cell suspension. Cell viability and counts were determined using a hemocytometer by trypan blue exclusion. $50 \times 10^{6}$ viable cells were aliquoted to a $1.5 \mathrm{ml}$ sterile Eppendorf centrifuge tube. The cells were washed and microcentrifuged at $400 \mathrm{~g}$ for $3 \mathrm{~min}$. Prior to surgery we resuspended the cell pellet in $1 / 2 \mathrm{ml}$ of Pucks-EDTA. Cell clumps were dissociated by gentle pipetting with a Pasteur pipet prior to loading the cells into the microsyringe.

\section{Cell line transplantation}

Prior to striatal surgery, we injected animals intraperitoneally with $10 \mathrm{mg} / \mathrm{kg}$ of cyclosporin A (provided by Sandoz Pharmaceutical Corp., East Hanover, NJ). Tissue culture cells were injected into a single site in the caudate-putamen. Cau- date-putamen site coordinates from bregma were AP $+0.2 \mathrm{~mm}, \mathrm{~L}-3.2 \mathrm{~mm}$, and D $-6.5 \mathrm{~mm}$. $10 \mu \mathrm{l}$ of Pucks solution, in which the cells were suspended, was gradually injected at $1 \mu \mathrm{l} /$ minute using a Hamilton 26 gauge $25 \mu$ l syringe. The needle and syringe were left in place for an additional 10 minutes and then slowly withdrawn. Animals remained on an $8 \mathrm{mg} / \mathrm{kg}$ daily dosage of cyclosporin that was continued for the duration of the experiment to prevent rejection of the cellular graft. Animals which were not given cyclosporin failed to show evidence of cell survival.

\section{Sacrifice, tissue handling, and histochemical technique}

Animals were sacrificed by a lethal dose of intraperitoneal nembutal and then decapitated. The skull was opened rapidly and the entire brain removed. For TH immunohistochemistry, the brain was fixed for 3 days in $4 \%$ paraformaldehyde in phosphate buffered saline ( $\mathrm{pH}$ 7.4). After fixation, a block was dissected surrounding the cell graft in the left caudate-putamen. The tissue block was then stored in a solution of $30 \%$ sucrose $/ 0.1 \mathrm{M}$ PBS/0.1\% sodium azide prior to cutting $15 \mu \mathrm{m}$ coronal sections.

TH immunohistochemistry was performed on brain sections. Nickel intensification of TH immunohistochemistry, cresyl violet, and hemotoxylin and eosin (H\&E) staining were also performed on some tissue sections. Sections for TH staining were incubated overnight at $4^{\circ} \mathrm{C}$ with anti-tyrosine hydroxylase anti-serum (Eugene Tech International, Inc., diluted 1:50 in 0.1\% BSA, $0.1 \%$ Triton-X 100 in PBS). Primary antibody was detected with Vectastain ABC kit (Vector Laboratories), using biotinylated goat-anti-rabbit antibody, HRP-labeled $A B C$ reagent and 3-3'diaminobenzadine tetra hydrochloride (Vector) as chromagen. Every third section was processed as recommended by the manufacturer.

For catecholamine fluorescence, snap-frozen brain sections were processed with sucrose-potassium phosphate-glyoxylic acid (SPG) solution 130/. This SPG method has a high specific sensitivity for monoamines $/ 8,9 \%$. We selected WC5 and PC12 cells as controls for the SPG preparation. WC5 is characteristically negative while 
PC12 cells are known positive. These sections were examined with an Olympus Vanox fluorescence microscope (equipped with a $455 / 490 \mathrm{~nm}$ band pass excitation filter, a 500 beam-splitting mirror, and $515 \mathrm{~nm}$ emission barrier filter). Bluegreen fluorescence in tumor cells is specific for catecholamines $/ 8 /$.

\section{RESULTS}

\section{Rotational behavior}

Table 1 presents for each group the means and standard deviations for Baseline and Post-transplant rotations/minute. The ANOVA showed no statistically significant differences in Baseline means.

Table 2 presents for each group the means and standard deviations for the Change and Percent Improvement measures. The mean Change is significantly different from zero for the LA-N-6 and SMS-LHN groups $(p=0.0015$ and $p=0.0066$, respectively). The mean Percent Improvement is significantly different from zero for the LA-N-6 and SMS-LHN groups $(p=0.0027$ and $p=0.0001$, respectively) and borderline significant for the SHAM group $(p=0.0111)$.

For comparison of the four groups the ANOVA showed no statistically significant group differences in Change means $(p=0.0638)$. There was a statistically significant group difference in mean Percent Improvement $(p=0.0006)$. Bonferroni pairwise comparisons (at $\alpha=0.01$ ) revealed a statistically significant difference only between SMS-LHN and SMS-KCN. Relaxing the Bonferroni level of significance to 0.05 allowed us to identify three pairwise significant group differences in Percent Improvement: LA-N-6 vs. SMSKCN, SMS-LHN vs. SMS-KCN and SMS-SHN vs. SHAM.

Figure 1 shows rotational behavior over the 30 days post-transplant for each transplant group. Prior to transplantation, the number of rotations induced by apomorphine in the 6-OHDA lesioned hemiparkinsonian rats gradually increased and eventually plateaued. Decreases in rotations were evident by one week after transplantation, and remained at approximately the same value until
TABLE 1

Pre- and post-transplant values: mean (SD) (rotations/minute)

\begin{tabular}{llll} 
Group & $n$ & $\begin{array}{l}\text { Pre-transplant } \\
\text { (Baseline)* }\end{array}$ & Post-transplant \\
\hline & & & \\
SMS-LHN & 8 & $17.3(17.0)$ & $7.7(10.4)$ \\
LA-N-6 & 7 & $18.1(8.0)$ & $9.7(6.5)$ \\
SMS-KCN & 6 & $14.7(4.6)$ & $13.1(6.1)$ \\
SHAM & 6 & $21.0(8.9)$ & $14.9(3.9)$ \\
& & \\
"From the one-way ANOVA on Baseline values there is no evidence that \\
the groups have different means.
\end{tabular}

TABLE 2

Change and percent improvement: mean (SD) (rotations/minute)

Group Change ${ }^{\dagger} \quad$ Percent Improvement (\%)

\begin{tabular}{lll}
\hline & & \\
SMS-LHN & $9.54(7.07)$ & $60.5(17.2)$ \\
LA-N-6 & $8.33(4.02)$ & $51.8(27.9)$ \\
SMS-KCN & $1.50(1.90)$ & $13.1(15.9)$ \\
SHAM & $6.04(6.62)$ & $25.1(15.7)$ \\
ANOVA p-value* & 0.0638 & 0.0006 \\
\hline
\end{tabular}

t LA-N-6 $(p=0.0015)$ and SMS-LHN $(p=0.0066)$ Change means are each significantly different from zero (one-sample t-tests)

* LA-N-6 $(p=0.0027)$, SMS-LHN $(p=0.0001)$ and SHAM $(p=0.0111)$ Percent Improvement means are each significantly different from zero (one-sample t-tests)

- The p-values are from one-way ANOV. is comparing all four groups See the text for results of Bonferroni method pairwise comparisons performed on Percent Improved.

the animals were sacrificed (see Figure 1). Of the two animals that died prior to completion of the 10th measurement, one SMS-LHN rat died after the 6th measurement, and one SHAM rat died after the 4th measurement.

\section{Histology}

To determine the effectiveness of the lesion, frontal sections were cut through the SN and VTA. 


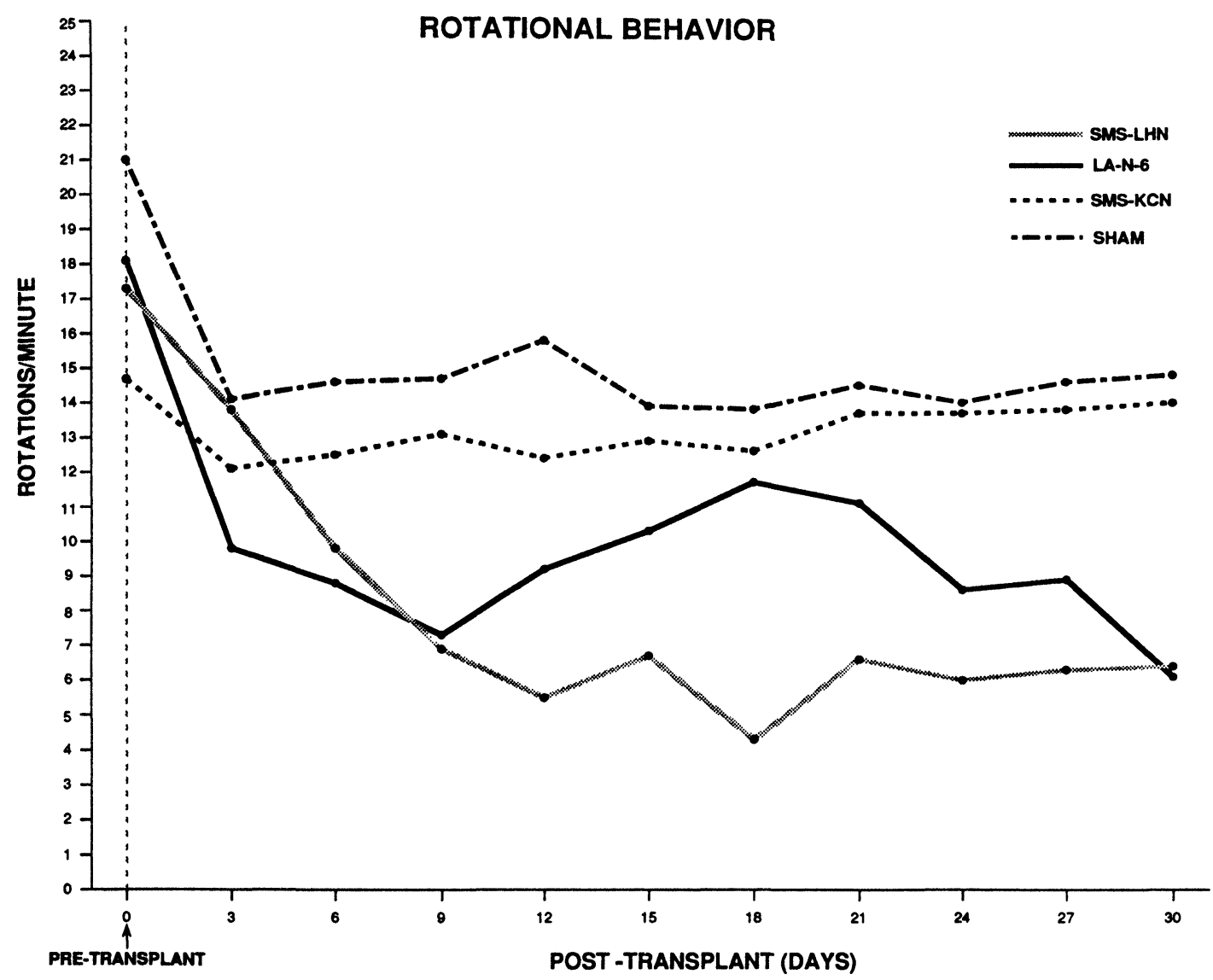

Fig. 1: Effect of SMS-LHN, LA-N-6, SMS-KCN, or SHAM transplants placed into the caudate nucleus of 6-OHDA lesioned rats. Rats receiving SMS-LHN and LA-N-6 showed significant improvement, (i.e., reduction in apomorphine-induced rotation) over time. Rats receiving SMS-KCN non-dopamine producing donor cells or sham surgeries showed some reduction in rotation which was not statistically significant.

Histochemical analysis of catecholamine activity in the region of the lesioned SN and VTA showed that the 6-OHDA had destroyed almost all THcontaining cell bodies (see Fig. 3A). There was also reduction in activity to background levels of TH-positive fine fibers and catecholamine-specific fluorescence on the lesioned side. Because questions have arisen in recent reports /17/ concerning the impact of unilateral lesions on the level of TH and the presence of other substances in the other hemisphere, we performed 2 pilot studies prior to this study, comparing $\mathrm{TH}$ reactivity in control animals without lesions to animals with unilateral 6-OHDA lesions. These unpublished studies examined 10 animals and showed no significant difference in $\mathrm{TH}$ reactivity between the control animals and $\mathrm{TH}$ reactivity from tissue con- tralateral to 6-OHDA lesions in the experimental animals. This analysis was performed by gross inspection of tissue stained for $\mathrm{TH}$.

At the time of death, four weeks after transplantation, there was no evidence of mass displacement on visual inspection of the coronal brain slices. The injection sites and needle tracks were easily seen on sections stained with $\mathrm{H} \& \mathrm{E}$. On microscopic examination 30 days post-transplant, surviving grafts from SMS-LHN, and LA-N6 , and SMS-KCN cell lines consisted of groupings of $\mathrm{TH}$ positive cells packed within and throughout the needle track. This was in contrast to rats sacrificed one or two days after transplantation in our preliminary work; these animals showed clumps of cells clustered at the base of the needle track. The comparison suggests significant multiplication of 

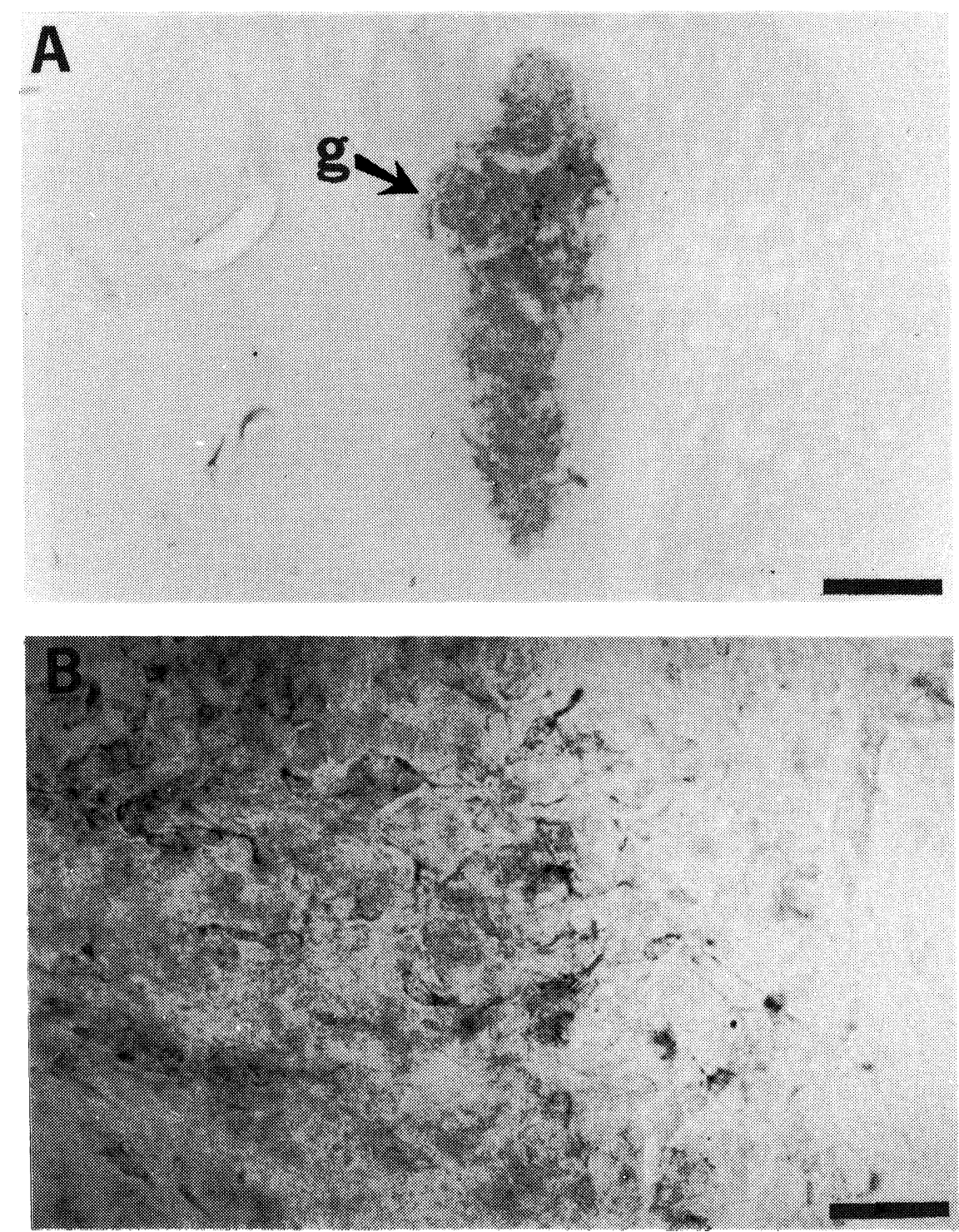

Fig. 2: A: Photomicrograph from the striatum of a 6-OHDA nigral lesioned rat with a $\mathrm{LA}-\mathrm{N}-6$ cell graft filling and somewhat expanding in the needle tract at 30 days post-transplant. The section was stained for tyrosine hydroxylase $(\mathrm{TH})$. $\mathrm{G}=$ graft. Scale bar $=0.5 \mathrm{~mm}$. B: High power photomicrograph of a TH stained SMS-LHN graft showing cell body staining at edge of graft and host tissue. Scale bar $=0.1 \mathrm{~mm}$. 

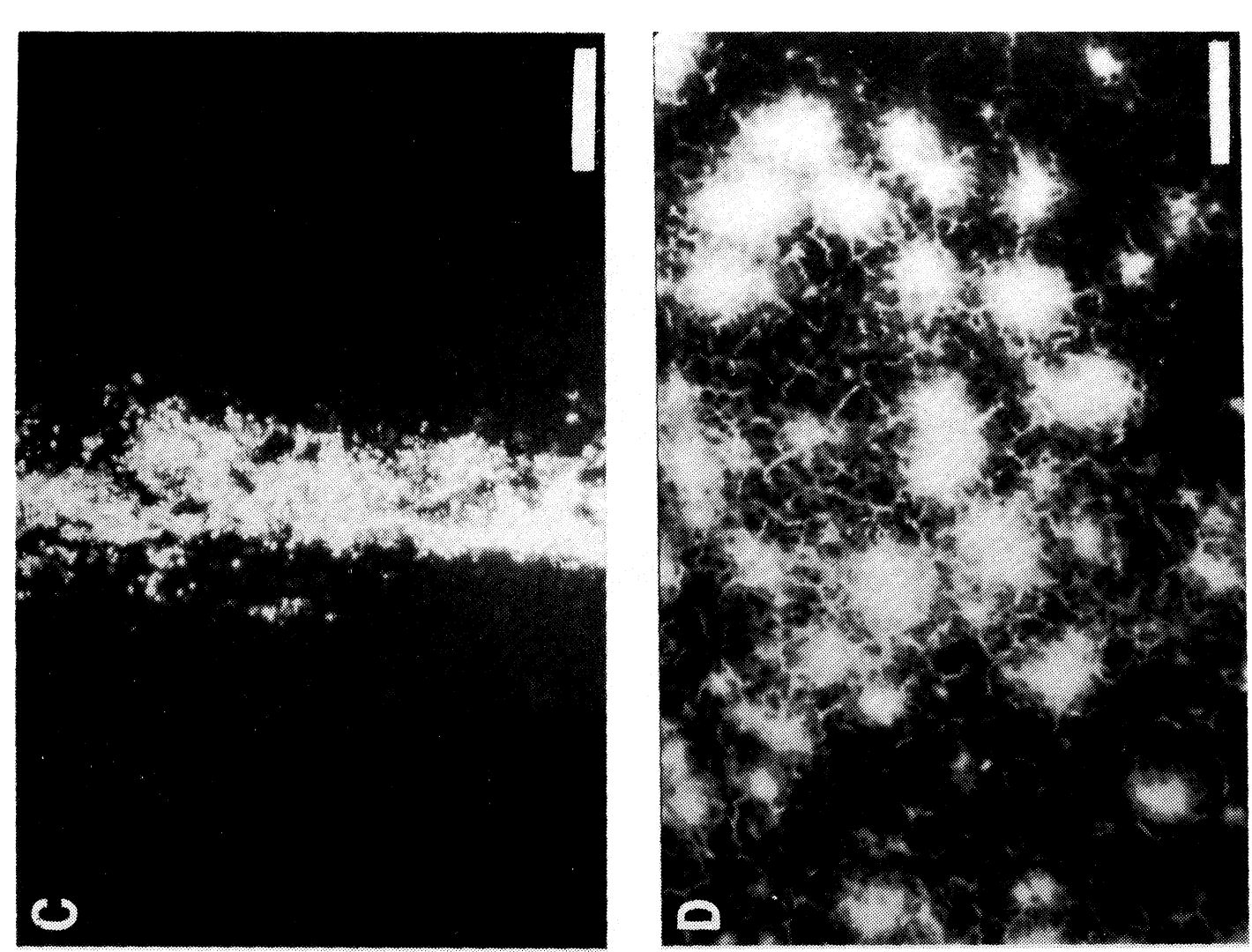

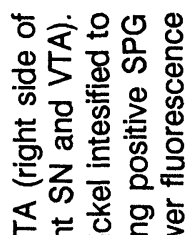

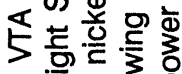
은

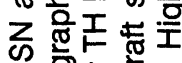
당흐음

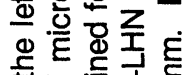
๘ $\therefore$ एँ $\sum_{\infty}$

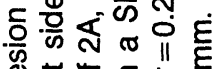

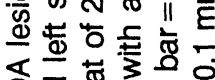

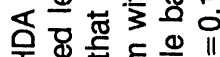

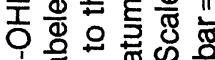

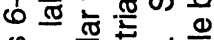
व

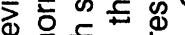
흐웡웡 ๙

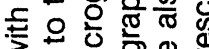
3 융ㅎㅀ ๘ ๘ 을응 \&

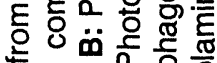

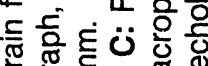
휸해 ह ह ह

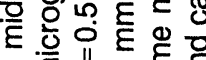

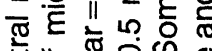
휴유에 >

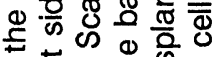

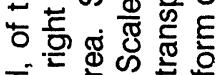
I至心

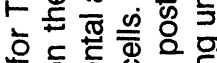
¿ 00

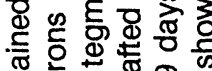

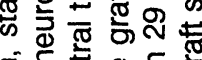

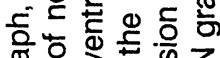
훙에 응으웡 은 $5 \%$ D है Ф

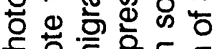
늘원동 के .

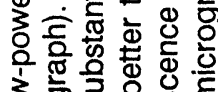

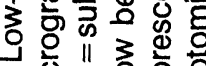

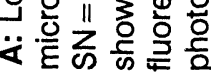
$\ddot{m}$ iำ 
the grafted cells by 30 days. The grafted cells did not appear to penetrate into the surrounding tissue of animals at 30 days (see Fig. 2A, B).

Histology of the SMS-LHN and LA-N-6 grafts showed viability, as determined by TH immunoreactivity (see Fig. 2B). In many of the animals there was TH staining in and around the graft site. Some animals also showed good TH staining on the side contralateral to the graft, while there was a nicely circumscribed TH positive graft on the grafted side. It appeared the $\mathrm{TH}$ activity was endogenous to the graft rather than a host response, since there was no apparent TH staining except immediately adjacent to the graft. Nickel intensification of TH staining of SMS-LHN and LA-N-6 grafts showed marking specific to TH antibody labeling (see Fig. 3B). Bright positive blue-green catecholamine fluorescence radiated from the cells, consistent with neurite outgrowth; however, because of clumping, clear processes were not visible at low power. At high power catecholamine fluorescence was clearly visible (see Fig. 3D). A diffuse fluorescence from the area surrounding the cells was also visible, suggestive of an active secretion of catecholamines and moderate diffusion (see Fig. 3C). No gradient was apparent. For the SMS-KCN grafts no fluorescing cells were found at the site of transplantation after the SPG procedure.

All cell lines exhibited uncontrolled growth in vivo, and therefore are not practical for transplant in animal studies of more than one month duration.

\section{DISCUSSION}

Results of this experiment show that apomorphine-induced rotational behavior in a hemiparkinsonian rat can be partially corrected by catecholaminergic dissociated cell grafts placed in the caudate-putamen.

The analysis indicates a statistically significant difference among groups in Percent Improvement in number of rotations/minute. The Bonferroni pairwise comparisons at the conservative 0.01 level of significance resulted in only one significant pairwise difference between SMS-LHN, with the (maximum) improvement of $60 \%$, and SMS-

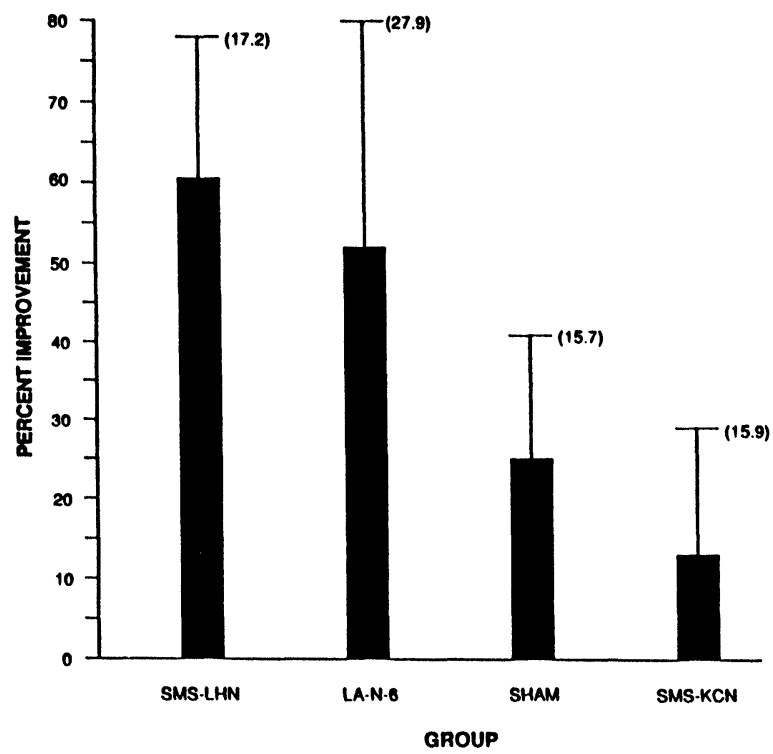

Fig. 4: Percent improvement and standard deviations for the four groups. LA-N-6 $(p=0.0027)$, SMS-LHN $(p=0.0001)$ and SHAM $(p=0.0111)$. SMS-LHN showed the greatest Percent Improvement. These Percent Improvement means are each significantly different from zero by one sample ttests.

$\mathrm{KCN}$, with the (minimum) improvement of $13 \%$ (see Fig. 4). Though other pairwise comparisons were not significant at $\alpha=0.01$ the data suggest that percent improvement is similar in the SMSLHN and LA-N-6 groups, and that these groups are different from both the SMS-KCN and SHAM groups which are similar.

The mean Changes, while not statistically different among the groups, are ordered in the same way as the Percent Improvement means; the smallest Change is in SMS-KCN and the largest is in SMS-LHN. This measure, Change, is more variable among animals, perhaps because it does not account for the inter-rat variability in baseline (pre-transplant) rotations/minute. Though lacking statistical significance the data suggest an effect similar to that found using Percent Improvement.

Several phenomena are at work in the present experiment. In view of the greater magnitude of reduction in circling associated with the catecholaminergic cell lines as compared to the two control procedures, it is reasonable to conclude that the former is probably producing dopamine, or having a unique effect on the surrounding 
brain which may be caused by the presence of an unknown neurotransmitter. It is puzzling that as the cell lines apparently divided and grew, there were no further reductions in rotational behavior. The question of the mechanism by which the rotational behavior is improved is presently under further investigation. Reports by Gerfen et al. /17/ have recently looked at the balance between nigrostriatal systems and the unknown factors involved in this rotational model, such as differences in an individual animal's response to apomorphine prior to lesioning. They have proposed that the system may have many complex and delicate interdependencies.

Returning to the present experiment, the data seem clear that the active cell lines, namely SMSLHN, and LA-N-6, have a beneficial effect on apomorphine-induced rotational behavior in the parkinsonian rat model. This is in addition to an injury-related effect seen in pure form in the sham procedures.

The cells employed here were neoplastic cells, coming from neuroblastoma lines. As we and others $/ 22$ / found, these cell lines continue to grow in number. Therefore, these cells are not suitable for long-term animal experimentation and particularly not for consideration in humans. However, if cell lines can be rendered amitotic in tissue culture, they may be useful for long term investigational use. Gash et al. /16/ rendered a human neuroblastoma cell lone amitotic and then grafted it into adult African green monkeys. The amitotic cells survived for up to 340 days, remained differentiated, and did not revert to an active mitotic state. Kordower et al. /22/ transplanted both mitotic and amitotic human neuroblastoma cell lines into rodents and found that both survived. However the amitotic lines had fewer surviving cells. Kordower's dopamine-producing cell lines also reversed lesion-induced parkinsonian defects in rats as demonstrated by maze testing. The present study adds to existing research because it includes a non-dopaminergic neuroblastoma graft that exhibited no dopaminergic activity and also produced no appreciable improvement in rotational motor deficit.

The concept of genetically engineering cells via oncogene insertion or some other method to produce immortal cells lines that carry specific neu- rotransmitter characteristics is exciting. Bredesen et al. $/ 6 /$, in a preliminary finding, have utilized genetically modified temperature-sensitive clonal neural cells for neural transplantation and suggest that this type of modification could by applied to cells of any neurotransmitter system. Since cloned genes may be inserted into cells prior to transplantation, the dopaminergic potential of transplanted cells could be enhanced. We are presently studying such nerve cell lines which are showing promise in both rodent and primate models.

\section{ACKNOWLEDGEMENTS}

We wish to acknowledge advice and guidance given by Dale Bredesen, Shirley G. Diamond, Jay Schneider, Noel Wheeler, and Marshall Grode, the laboratory assistance of John Brewer, Dan Stoller, and Shahrooz Rabizadeh and the secretarial assistance of Setsuko Kashitani.

\section{REFERENCES}

1. Aebischer P, Tresco PA, Winn SR, Greene LA, Jaeger CB. Long-term cross species brain transplantation of a polymer-encapsulated dopamine-secreting cell line. Exp Neurology 1991; 111: 269-275.

2. Allen GS, Burns RS, Tulipan NB, Parker RA. Adrenal medullary transplantation to the caudate nucleus in Parkinson's disease. Arch Neurol 1989; 46: 487-491.

3. Backlund EO, Granberg PO, Hamberger B. Transplantation of adrenal medullary tissue to striatum in parkinsonism. First clinical trials. J Neurosurg 1985; 62: 169-173.

4. Bing G, Notter MF, Hansen JT, Kellogg C, Kordower JH, Gash DM. Cografts of adrenal medulla with C6 glioma cells in rats with 6-hydroxydopamine-induced lesions. Neurosci 1990; 34: 687-697.

5. Bjorklund $A$, Lindvall $O$, Isacson $O$, Brundin $P$, Wictorin K, Strecker RE, Clarke DJ, Dunnett SB. Mechanisms of action of intracerebral neural implants. Trends Neurosci 1987; 10: 509-516.

6. Bredesen D, Hisanaga K, Sharp FR. Neural transplantation using temperature-sensitive immortalized neural cells: a preliminary report. Ann Neurol 1990; 27: 205-207.

7. Brundin P, Strecker RE, Widner H, Clarke DJ, Nilsson OG, Astedt B, Lindvall O, Bjorklund A. Human fetal dopamine neurons grafted in a rat model of Parkinson's disease: immunological aspect, spontaneous and drug-induced, and dopamine release. Exp Brain Res 1988; 70: 192-208. 
8. de la Torre JC, Surgeon JW. A methodological approach to rapid and sensitive monoamine histofluorescence using a modified glyoxylic acid technique: the SPG method. Histochem 1976; 49: 81-93.

9. de la Torre JC. An improved approach to histofluorescence using the SPG method for tissue monoamines. J Neurosci Methods 1980; 3: 1-5.

10. Donner L, Triche TJ, Israel MA, Seeger RC, Reynolds CP. A panel of monoclonal antibodies which discriminate neuroblastoma from Ewing's sarcoma, rhabdomyosarcoma, neuroepithelioma, and hematopoietic malignancies. Prog Clin Biol Res 1985; 175: 347-366.

11. Freed CR, Breeze RE, Rosenberg N, Schneck SA, Wells TH, Barrett JN, Grafton ST, Huang SC, Eidelburg D, Rottenburg DA. Transplantation of human fetal dopamine cells for Parkinson's disease. Arch Neurol 1990; 47: 505-512.

12. Freed WJ, Adinolfi AM, Laskin JD, Geller HM. Transplantation of $\mathrm{B} 16 / \mathrm{C} 3$ melanoma cells into the brains of rats and mice. Brain Res 1989; 485: 349-362.

13. Freed WJ, Geller HM, Poltorak M, Cannon-Spoor HE, Cottingham SL, LaMarca ME, Schultzberg M, Rehavi M, Paul S, Ginns EI. Genetically altered and defined cell lines for transplantation in animal models of Parkinson's disease. Prog Brain Res 1990; 82: 1121.

14. Freed WJ, Hoffer BJ, Olson L, Wyatt RJ. Transplantation of catecholamine containing tissues to restore the functional capacity of the damaged nigrostriatal system. In: Sladek JR, Gash DM, eds, Neural Transplants: Development and Function. New York: Plenum Press, 1984; 373-406.

15. Gash DM. Neural transplants in mammals. A historical overview. In: Sladek JR, Gash DM, eds, Neural Transplants: Development and Function. New York: Plenum Press, 1984; 1-12.

16. Gash DM, Notter MFD, Okawara SH. Amitotic neuroblastoma cells used for neural implants in monkeys. Science 1986; 233: 1420-1422.

17. Gerfen C, Engber T, Mahan L, Susel Z, Chase TN, Monsma FG Jr, Sibley DR. D1 and D2 dopamine receptor-regulated gene expression of striatonigral and striatpallidal neurons. Science 1990; 250: 14291432.

18. Goetz CG, Olanow CW, Koller WC, Penn RD, Cahill D, Morantz R, Stebbins G, Tanner CM, Klawans HL, Comella CL, Witt T, Cox C, Waxman M, Gauger L. Multicenter study of autologous adrenal medullary transplantation to the corpus striatum in patients with advanced Parkinson's disease. N Engl J Med 1989; 320: 337-341.

19. Hefti F, Hartikka J, Schlumpf M. Implantation of PC12 cells into the corpus striatum of rats with lesions of the dopaminergic nigrostriatal neurons. Brain Res 1985; 348: 283-288.

20. Horellou P, Marlier L, Privat A, Mallet J. Behavioral effect of engineered cells that synthesize L-DOPA or dopamine after grafting into the rat neostriatum. Eur J Neurosci 1990; 2: 116-119.

21. Jaeger CB, Greene LA, Tresco PA, Winn SR, Aebischer P. Polymer encapsulated dopaminergic cell lines as "alternative neural grafts". Prog Brain Res 1990; 82: 41-46.

22. Kordower JH, Notter MF, Gash DM. Neuroblastoma cells in neural transplants: a neuroanatomical and behavioral analysis. Brain Res 1987; 417: 85-98.

23. Lindvall O, Rehncrona S, Brundin P, Gustavi B, Astedt B, Widner $\mathrm{H}$, Lindholm T, Bjorklund A, Leenders KL, Rothwell JC, Frackowiac R, Marsden CD, Johnels B, Steg G, Freedman R, Hoffer BJ, Seiger A, Bygdeman M, Stromberg I, Olson L. Human fetal dopamine neurons grafted into the striatum in two patients with severe Parkinson's disease. Arch Neurol 1989; 46: 615-631.

24. Lindvall $O$, Brundin $P$, Widner $H$, Rehncrona $S$, Gustavii G, Frackowiac R, Leenders KL, Sawle G, Rothwell JC, Marsden CD, Bjorklund A. Giafts of fetal dopamine neurons survive and improve motor function in Parkinson's disease. Science 1990; 247: 574-577.

25. Lu SY, Giordano M, Norma AB, Shipley MT, Sanberg PR. Behavioral effects of neural transplants into the intact striatum. Pharm Biochem Behav 1990; 37: 135148.

26. Madrazo I, Franco-Bourland R, Ostrosky-Solis F, Aquilera M, Cuevas C, Zamorano C, Morelos A, Magallan E, Quizar-Sahagun G. Fetal homotransplants (ventral mesencephalon and adrenal tissue) to the striatum of parkinsonian subjects. Arch Neurol 1990; 47: 1281-1285.

27. Perlow MJ, Freed WJ, Hoffer BJ, Seiger A, Olson L, Wyatt RJ. Brain grafts reduce motor abnormalities produced by destruction of nigrostriatal dopamine system. Science 1979; 204: 643-647.

28. Reynolds CP, Biedler JL, Spengler BA, Reynolds DA, Ross RA, Frenkel EP, Smith RG. Characterization of human neuroblastoma cell lines established before and after therapy. JNCI 1986; 76: 375-387.

29. Reynolds CP, Tomayko MM, Donner L, Helsen L, Seeger RC, Triche TJ, Brodeur GM. Biological classification of cell lines derived from human extra-cranial neural tumors. Prog Clin Biol Res 1988; 271: 291-306.

30. Reynolds CP, German DC, Weinberg AG, Smith RG. Catecholamine fluorescence and tissue culture morphology: Techniques in the diagnosis of neuroblastoma. AJCP 1981; 75: 275-282.

31. Sladek JR, Gash DM. Nerve-cell grafting in Parkinson's disease. J Neurosurg 1988; 68: 337-347.

32. Strecker R, Miao R, Loring J. Survival and function of aggregate cultures of rat fetal dopamine neurons grafted in a rat model of Parkinson's disease. Exp Brain Res 1989;76: 315-322.

33. Ungerstedt U. Stereotaxic mapping of the monoamine pathways in the rat brain. Acta Physiol Scand Suppl 1971; 367: 1-48. 
34. Ungerstedt U. Postsynaptic supersensitivity after 6hydroxydopamine induced degeneration of the nigrostriatal dopamine system. Acta Physiol Scand Suppl 1971; 367: 69-93.

35. Ungerstedt U. Striatal dopamine release after amphetamine or nerve degeneration revealed by rotational behavior. Acta Physiol Scand Suppl 1971; 367: 49-68.

36. Ungerstedt U, Arbuthnott G. Quantitative recording of rotational behavior in rats after 6-hydroxy-dopamine lesions of the nigrostriatal dopamine system. Brain Res 1970; 24: 485-493.

37. Whittemore SR, Holets VR, Keane DJ, Levy DJ, McKay RDG. Transplantation of a temperature-sensitive, nerve growth factor-secreting, neuroblastoma cell line into adult rats with fimbria-fornix lesions rescues cholinergic septal neurons. J Neurosci Res 1991; 28: 156-170. 

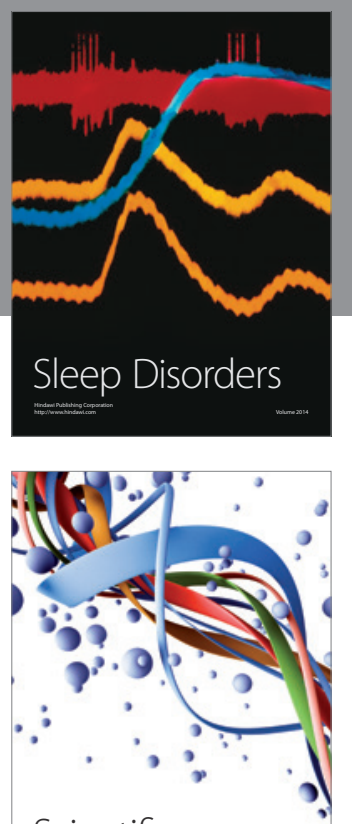

Scientifica
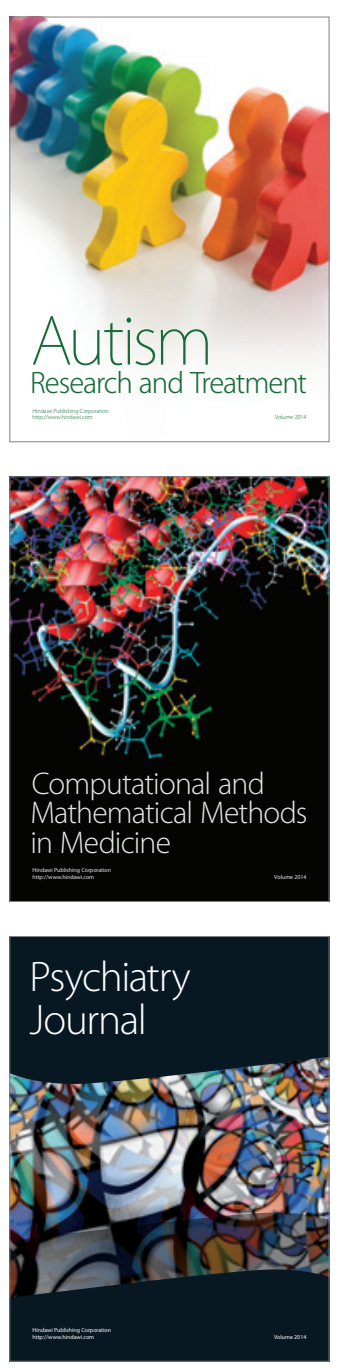
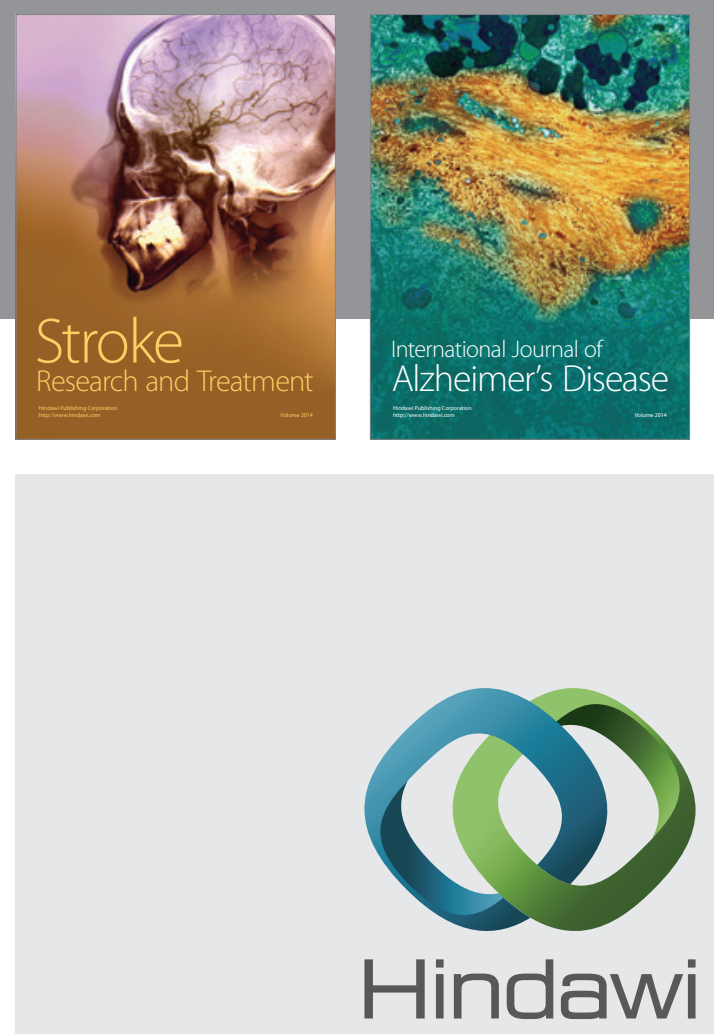

Submit your manuscripts at

http://www.hindawi.com
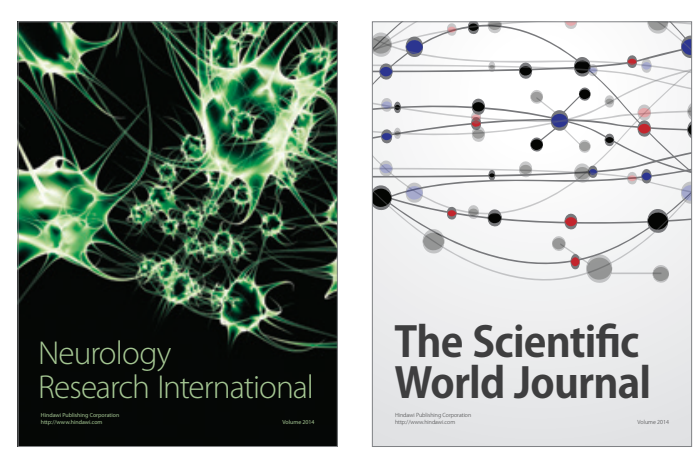

The Scientific World Journal

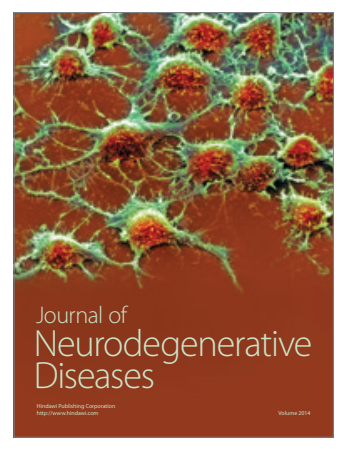

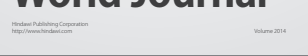

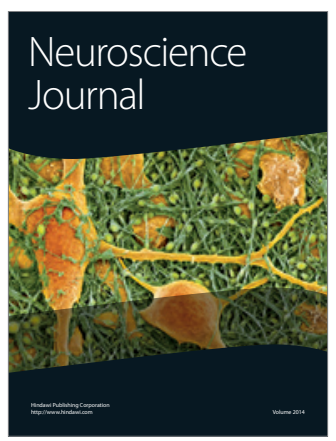

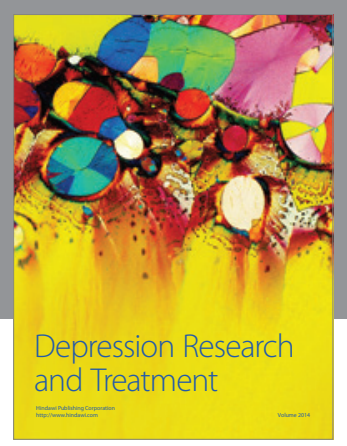
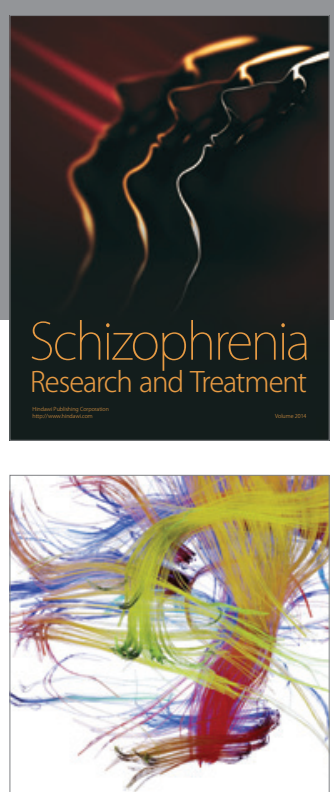

Brain Science

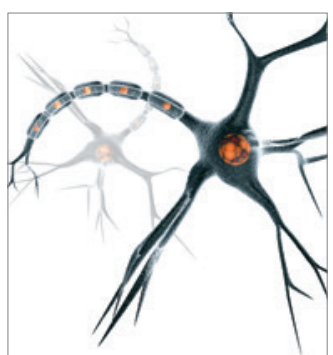

Neural Plasticity
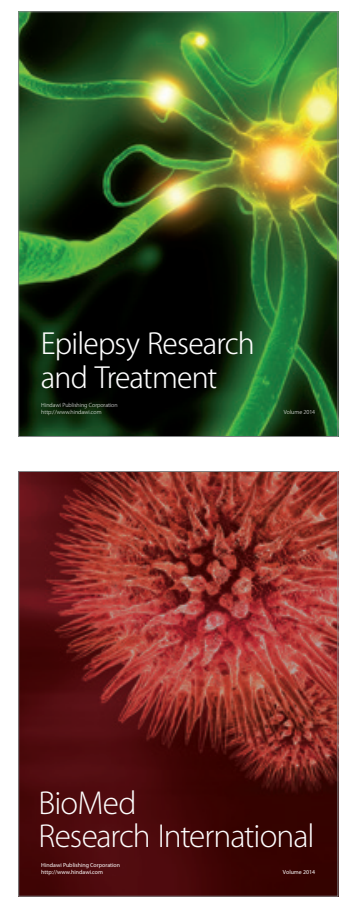

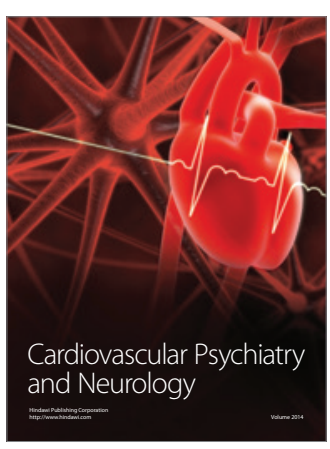

Parkinson's

Disease
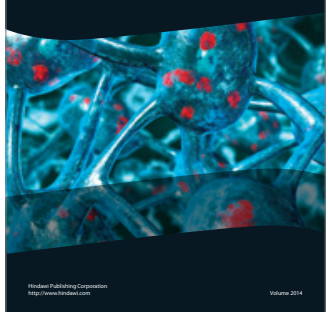